\title{
Glimt fra kulturrevolutionen i Irans gader Vibeke Sperling
}

Når revolutionen tæver, æder og myrder sine egne børn, er det begyndelsen til enden for den. Iranerne har med større styrke end hidtil set vist, at de er Mellemøstens mest forandringsparate folk

Først kom Teherans unge i store jublende flokke med grønne pandebånd og grønne bånd om armene. Så kom sorte flokke af politi på rappe motorcykler med tåregas og knipler, som de slog vildt om sig med, assisteret af Basij-militsen, det frivillige religiøse tæskehold. Det var før og efter præsidentvalget 12. juni.

Jeg landede i Imam Khomeini lufthavnen i Teheran om natten til fredag, præcis en uge før valget. Hermed mine dagbogsnoter fra 11 dage, der rystede Iran:

5. juni: Teheran bobler af valgkampsenergi, og alle taler om præsidentkandidaternes tv-dyster. Det er første gang i den islamiske republiks historie, at kandidaterne diskuterer for åben skærm, to og to i hele halvanden time. Første dyst - imellem spidskandidaterne, præsident Mah- moud Ahmadinejad og reformkandidaten Mir-Hossein Mousavi - har de seneste dage bragt titusinder til gadefest for den forventede sejr for Mousavi. Klokken fire om morgenen er det svært at nå mit hotel på Valiasr Boulevarden, festens hovedgade.

6. juni: "Bye-Bye Ahmadinejad. HiHi Mousavi”, gjalder råbene i gaderne. Der ses kun få politibetjente og slet ingen af de moralbetjente, der plejer at arrestere kvinder, som præstestyret finder for let påklædte, og alle, som råber højt eller spiller høj musik. Besøg på en politistation efter, at jeg var frarøvet min taske, gav sidegevinst. En politiinspektør bekræfter, at ordenshåndhæverne havde ordre til at holde lav profil. "Vi får afviklet ferie og klaret bureaukrati, men har selvfølgelig folk para- 
te, hvis der sker noget alvorligt", sagde han. Pludselig var råb og skrig i gaderne ikke 'noget alvorligt'.

\section{7. juni: Medierne trækker tidligere} prognoser om lav valgdeltagelse tilbage og venter nu rekordstort vælgerfremmøde. Den Øverste Leder Ali Khamenei bifalder tv-debatterne. Han siger endog, at han "nyder ytringsfriheden". Mere demokratiske vinde blæser som regel i iranske valgkampe, men denne gang er omfanget af frihed kommet bag på alle - også de unge i gaderne.

Det er så usædvanligt, at det næsten lyder naturligt, at Khamenei taler om ytringsfrihed. Men han er utilfreds med tonen og kræver, at debatterne "holder sig inden for de religiøse rammer". Hans kritik er især rettet til Ahmadinejad, der bl.a. har anklaget tidligere præsident, ayatollah Hashemi Rafsanjani, for korruption. Splittelsen i regimet er brudt ud i lys lue.

8. juni: Ahmadinejad siger i tv-dysten med den konservative kandidat Mohsen Rezai: "100 lande har nu overtaget vores styreform". Han afviser at nævne nogen af dem. Om aftenen råbes i gaderne: "Ahmadinejad gør igen Iran til globalt grin”.

Under valgfesten var det tydeligt, at mobiliseringen ikke mindst omfattede iranere, der i mange år havde vendt ryggen til politik, fordi politik var reduceret til inkarnationen af præstestyret. "Jeg blev genfødt som politisk dyr, da jeg så de første unge i gaderne forleden", siger en skolelærer, der var aktiv under den islamiske revolution i 1979.

Min tolk oversætter en avishistorie om, at seks Ahmadinejad-tilhængere er gået i sultestrejke, indtil valget er overstået: "De vil sultestrejke sig til døde, hvis Ahmadinejad taber. De kan ikke leve med nogen som helst anden præsident".

\section{9. juni: Stadig flere demonstranter} bærer valgplakater med et færdselsskilt med teksten: 'Forbudt at lyve', rettet imod Ahmadinejads tale om økonomien og udenrigspolitikken som 'guddommelige succeser' i hans fire år ved magten. Mange sammenligner stemningen med den islamiske revolution i 1979 og den fremdrift af unge, der dengang drev shahen fra magten. "Vi kan igen vælte magten, også selv om vi bliver slået tilbage. Det kan kun blive midlertidigt", siger historiestuderende Shirin, der er blandt de 'rationelle', som hun siger, der ikke tror, at regimet vil tillade sejr for Mousavi.

Der råbes: "Rock i stedet for sørgemusik" på 20-årsdagen for revolutionens far, ayatollah Khomeinis død.

Det er tydeligvis ikke en revolution imod præstestyret, der er i gang. I hvert fald ikke endnu. Kvinderne lader ikke tørklæderne falde, som ved enkelte tidligere demonstrationer. Den brand af kærlighed til Mousavi, som er tændt få dage forinden, har fået mange unge til at 
tale om, at målet er at støtte "en liberal form for forsvar for revolutionen".

10. juni: Det hidtil største valgmøde for Ahmadinejad i det enorme Masala moskekompleks i Teheran. Hundredtusinder råber hans kælenavn: "Ahmadi, hvor er du?". De har ventet i over to timer, men præsidenten kommer ikke, da han angiveligt ikke kan komme igennem folkemængderne uden for moskeen.

Jeg møder hans søster Parvin Ahmadinejad i moskeen. Hun siger, at broderen "ikke vil bringe liv i fare ved at insistere på at komme igennem mængden. Hans kærlighed til den store iranske familie vinder også i dag".

En iransk avis melder om, at der i den sidste uge hver dag er sendt gennemsnitlig 90 millioner sms'er. "Om ikke af anden grund, så har vi grebet om præsterne denne gang, fordi vi har mobilerne og magten over internettet", siger den jurastuderende Manoush.

\section{1. juni: Flere slutter sig til gadefest-} en med hundredtusinder, ja nogle journalister anslår over en million, ved afslutningen på valgkampen. Mens det primært var de unge, som festede den første uge, ses nu mange flere ældre og gamle, samt hele familier med børn. Spærretiden er sat ind, og der loves hårde straffe til dem, som krænker forbuddet imod valgkampagne fra 24 timer, før valglokalerne åbner.
12. juni: I det nordlige og centrale Teheran er det overordentlig svært at finde vælgere, som vil stemme på Ahmadinejad. Det er Mousavi, som uden tvivl vinder denne del af hovedstaden. I fattigkvartererne i syd ser det noget anderledes ud. Her stemmer 55-60 procent for Ahmadinejad i min exit poll med over 100 adspurgte.

Det er endnu en forbløffende udstilling af midlertidig frihed, hvor ting, som er usete i vestlige valglokaler, lader sig gøre. I en moske i byens centrum snakker vælgere, lænet op ad valgborde, lystigt om, hvem de har stemt på: Mousavi for langt de fleste vedkommende. "En af reformkandidaterne", siger et par stykker.

Jeg ser det første valgresultat sammen med en universitetslærer, som har analyseret alle valg siden revolutionen. På grundlag af fire millioner optalte stemmer står Ahmadinejad til 69 procent. Valgeksperten siger: "De har besluttet sig for at svindle stort med resultatet. Sådan er vi aldrig blevet præsenteret for de første resultater".

Normalt kommer resultaterne distrikt for distrikt og region for region. Dagen efter, da flere delresultater foreligger, siger valgeksperten, at vælgerne stik imod sædvane ved iranske valg har stemt næsten ens på land og i by. "og ligeledes stik imod sædvane har de ikke stemt på kandidater fra deres hjemegn". Selv om Mousavi kommer fra det største mindretal, azerierne (aserbajdsja- 
nere), har Ahmadinejad ifølge det officielle resultat med over 70 procent af stemmerne fået et af sine bedste valg i Tabriz, hovedstaden i den nordlige aserbajdsjansk befolkede del.

Ahmadinejad og Mousavi erklærer sig begge som valgets vinder.

\section{3. juni: Ahmadinejad erklæres vin-} der med 63 procent af stemmerne imod 34 til Mousavi. Khamenei kalder Ahmadinejads genvalg et 'guddommeligt mirakel'.

De to andre kandidater, tidl. parlamentsformand og reformist Mehdi Karroubi og tidl. leder af Revolutionsgarden, Mohsen Rezai, får kun omkring en procent af stemmerne hver og kræver som Mousavi omvalg. Politiet og den religiøse milits Basij intensiverer angreb på demonstranter. Basij lever meget hurtigt op til sit øgenavn 'Revolutionsgardens tæskehold'.

Vi er mange, som søger til Mousavis valghovedkvarter, men nægtes adgang af et stort politiopbud. Der gives ordre til at rydde gaden, og vi stormer afsted med hævede knipler bag os. Jeg ser tilbage på en knippel på vej imod mit hovede. En anden politibetjent holder armen tilbage og råber: "Slå ikke på udenlandske journalister". Han brøler: "Nu skal de alle bankes ud af Iran".

Khamenei beder Vogternes Råd om at undersøge anklager om valgsvindel fra Ahmadinejads tre modkandidater. "Det er politisk selvmord, at han allerede har godkendt valget”, siger den økonomistuderende Mohsen.

14. juni: Vogterne Råd, der har godkendt kandidaterne, erklærer sig villig til omtælling af stemmerne i valgkredse med 'eventuelle uregelmæssigheder'. Mousavi siger, at samtlige stemmer må tælles om. Mindst otte meldes dræbt i Teheran, og flere demonstranter dræbt i andre byer.

\section{5. juni: Imam Khomeini Lufthav-} nens afgangshal er omdannet til studiekredse med journalister og mange eksiliranere, der havde været hjemme for at stemme. Her er flere iransk-amerikanere, som kunne have stemt ved valgsteder, der var oprettet i USA, selv om der ikke er diplomatiske forbindelser imellem de to lande.

"Jeg måtte hjem for at stemme, så jeg kombinerede det med min årlige ferie. Jeg er rædselsslagen for, hvad der nu kan ske med min familie i Isfahan. Især mit brushoved af en nevø, der ikke længere vil finde sig i sørgemusikken for diverse imamer", siger en kvinde, der glæder sig lige så meget som jeg til at lade tørklædet falde, når vi er inde i KLM- flyet til Amsterdam.

Jeg havde dog hellere været tvunget til at beholde tørklædet på en tid endnu, men som mange andre udenlandske journalister fik jeg nej til min ansøgning om forlængelse af visum. 


\section{Stilfærdig sekularisering}

Jeg forlader Iran med en fornemmelse af en igangværende sekularisering, som vil fortsætte, uanset resultatet af konfrontationerne efter valget. Jeg mærkede det mest i min højre hånd.

En universitetslektor sagde smilende til min forvirrede hånd, da han rakte sin frem: "Det er et af udtrykkene for de seneste års stilfærdige sekularisering".

Så sent som for tre år siden, da jeg sidst besøgte Iran, oplevede jeg ikke fremstrakte mandehænder som nu. Det sker ikke i det offentlige rum, men rundt omkring på kontorer, i institutioner og i privathjem. En advokat, som støtter Ahmadinejad, gør det også. Selv en præst, der mener, at kollegerne "er helt galt på den, når de tolker koranen, som om den forbyder os kontakt med fremmede kvinders hænder". Præsten mener, at der er brug for "at bryde dette tabu, for det forkvakler unges som ældres følelsesliv og seksualitet, som er givet af Allah".

Når det gælder det påbudte tørklæde, er det i Teheran og andre store byer gledet om muligt endnu mere ned i nakken, end da jeg var her sidst. "Vi eksperimenterer med tørklædernes G-streng", som en udfordrende klædt teenager siger.

Selv meget traditionelle kvinder, der altid bærer den fulde sorte chador, fortæller, at sæder og skikke også ændrer sig i deres familier. "Vi tager jo altid chadoren af, når vi er inden for hjemmets fire vægge. Det nye er, at jeg og mange af mine veninder ikke længere tager tørklæde på, når vi får besøg af mænd uden for familien eller helt fremmede. Det synes min mand er helt fint", siger den hjemmegående husmor Jasmin, der stemte på Ahmadinejad. Hendes veninde fortæller, at hendes mand er imod det og siger: "Jeg har gjort ham klart, at jeg vil skilles, hvis han ikke tillader mig det ekstra lille frirum". Hun har heller ikke noget imod at fortælle, at hun går meget op i at have dristigt undertøj på: "Det giver mig bekræftelse på, at alt under chadoren er mit helt eget".

Jeg drager i byen med to iranske veninder for at få besvaret spørgsmålet: Hvad gemmer sig under chadoren? Vores taxa har påskriften Kvindetaxa. $\mathrm{Og}$ vi er kun kvinder, så det går.

I Mehran Gaden i Teherans centrum hedder det på skilte ved mange butikker: 'Adgang forbudt for mænd'. Her sælges kvindeundertøj. Det er mænd, som ejer butikkerne, men de må ikke sælge produkterne, der heller ikke må udstilles i vinduerne.

"Kunderne efterspørger stadig mere frækt undertøj”, siger en ekspedient.

Til spørgsmålet om iranske kvinder går mere op i det frække undertøj end vestlige kvinder, der frit kan vælge udstyr fra inderst til yderst, siger hun: 
"Det er nok rigtigt. Kroppen er et frirum under de påtvungne gevandter. Også kvinder uden mænd går meget op i at udstyre den attraktivt. Og der er ingen forskel på kvinder i chador og i manteau".

Det franske ord manteau bruges om de halvlange skjorter og bluser, som de fleste kvinder har skiftet til i de store byer.

\section{Mousavi blandt G-strenge}

Det er før valget og i mange butikker hænger plakater for Mousavi mellem bh'er og trusser, herunder G-strenge. Hele gaden støtter Mousavi, bortset fra ekspedienten i en brudebutik. Hun støtter Ahmadinejad og hans krav om 'anstændige kvinder'.

Vanerne omkring bryllupper er også ændret. Ekspedienten fortæller: "Ja, det er en sand revolution. Men restauranterne er meget kede af den, fordi de taber penge. Stadig flere holder bryllup under private former, så mænd og kvinder kan feste sammen i stedet for i to forskellige lokaler på en restaurant".

Hun mindes sit eget bryllup få år efter revolutionen, hvor hendes mand var den eneste, som måtte komme ind i kvindernes afdeling: "Han kom nogle gange, og hver gang blev kvinderne advaret på forhånd, så de kunne tage chadoren på”.

Et par af brudekjolerne overlader kun meget lidt af brysterne til fantasien. "Men bruden er selvfølgelig dækket til med sjal og tørklæde. Kun veninderne og ægtemanden ser barmen".

Andre fortæller, at når der festes privat, kan der også serveres alkohol, der ikke er svært at få. Der cirkulerer telefonnumre og leverancerne kommer med bud. Men kunderne informeres jævnligt om nummerskift, da moralpolitiet er efter spritleverandører.

En fransk kvinde fortæller, at de fik masser af champagne bragt, da hun blev gift med en forretningsmand i Isfahan: "Moralpolitiet kom $o g$ ville arrestere min mand. Men da jeg kom til døren, lod de ham slippe, fordi han havde giftet sig med en udlænding".

Det kan forbløffe, at iranere drikker, når de ved, at de kan få pisk eller det, som er værre for dem. Den franske kvinde Marie siger: "Folk er meget forsigtige, men det er et af mange udtryk for den stille civile protest blandt også mange upolitiske".

I en park sidder kvinder og nyder at lade solen falde i deres frigivne hår. Det er ikke et oprør "men en af de sikkerhedsventiler, som regimet tillader for at dæmme op for vores frustration", siger en kvinde i en af de parker, der er reserveret kvinder indtil kl. 17.00.

Igen forbløffer iraneres åbenhed. Da jeg besøgte landet første gang for otte år siden, skiftede jeg helt syn på det, som foregik. Internationale medier havde givet mig indtryk af et folk, der var trampet under 
fode og i hvert fald ikke turde tale frit med udlændinge. Det gjorde de og leverede en lige så hård kritik af præstestyret, som man kunne læse i Vesten - bortset fra, at den iranske kritik var mere indsigtsfuld.

\section{Kulturrevolution og kup}

En kunstudstilling besøges af en kvindelig maler, der ikke må udstille det værk, som hun ser som sit allerbedste, et dobbeltportræt af en kvinde, med og uden hijab . Hun må heller ikke bringe de to billeder ud af Iran.

Hun lover at vise mig det, men så bryder volden ud i Teheran og hun vælger at blive hos en malerkollega $\mathrm{i}$ Isfahan. "Jeg tør ikke komme til Teheran nu. Det er slemt her i Isfahan, men værre der", siger hun til min tolk i telefonen.

Hun kan ifølge en kollega regne med at være på listen over de personer, der skal hentes i deres hjem, som regel om natten. Han siger: "Dette er jo frem for alt en kulturrevolution, så rebelske kulturpersonligheder er lige så udsatte som oppositionens politiske ledere og meningsdannere på universiteterne".

En følelsesmæssig rutsjetur på 11 dage at se angsten blive skyllet væk af folkelig begejstring. Så gråden og regulære nervesammenbrud, da kniplerne bankede angsten tilbage. En demonstrant sige: "Vi bliver i gaderne. Vi kan ikke bare lade troen på miraklet blive banket ihjel”. Men hvorfor var valgsvindlen så åbenlys? Meget tyder på, at det ikke var klodsethed, men netop hensigten. Det var efter alt at dømme meningen, at oppositionen skulle provokeres, "så opstanden imod tyveriet af folkets stemmer kan slås ned med hård hånd", sagde en iransk kommentator. Nu bad den traditionelt åbenmundede kommentator om anonymitet, efter at arrestationsbølgen var sat ind.

"Arrestationen af oppositionsledere viser, at deres primære angrebsmål er de mere moderate religiøse ledere", sagde professoren i politologi og videre: "Dette er et militærkup, foranstaltet af den magtfulde Revolutionsgarde. Hidtil har den beskyttet den islamiske revolution. $\mathrm{Nu}$ vil den i samarbejde med Ahmadinejad både styre og kontrollere revolutionen og statsapparatet. Det er en hidtil uset politisk førerrolle, som Revolutionsgarden søger at erobre med magt".

Revolutionsgarden er Irans vigtigste militærstyrke, meget bedre udrustet og trænet end hæren. Og Ahmadinejad har givet Revolutionsgarden kontrol med store fonde og centrale industrivirksomheder.

Energisektoren ses som revolutionsgardisternes vigtigste og enorme pengetank. Og Revolutionsgarden overvåger desuden Irans atomprogram.

Ahmadinejad har i vidt omfang militariseret den iranske regering, hvor der kun er én præst tilbage, 
propagandaministeren. Af resten er over halvdelen revolutionsgardister, resten teknokrater.

Den dansk-iranske lektor Ali Alfoneh skriver på hjemmesiden American Enterprise Institute, hvor han nu forsker: "Revolutionsgarden er mere aktiv end nogensinde før i støtten til præsident Ahmadinejad. Dens indblanding i valg er ikke noget nyt fænomen, men indblandingen i dette valg er den mest direkte nogensinde. Uafhængigt af resultatet er Den $\emptyset$ verste Leder Khamenei vinderen på kort sigt. Vinderen på lang sigt vil være Revolutionsgarden, der har erobret en ny, yderst hårdhændet rolle for sig selv i den politiske proces, som det for evigt vil være svært for Khamenei at stille noget op overfor".

\section{Militarisering uden sidestykke}

Revolutionsgardens direkte indblanding kunne ses under de første angreb på demonstranter efter offentliggørelse af 'valgresultatet'. De stod der på centrale pladser, men lod foreløbig Basij, der er underlagt Revolutionsgarden, tage sig af forsøg på at genoprette ro og orden. Demonstranter kaldte Revolutionsgardens opstilling rundt $i$ byen for 'helt usædvanlig' efter et valg og tilsyneladende en bevidst provokation.

"Det viser en militarisering uden sidestykke. Sådan gjorde vi aldrig i min tid", sagde en ældre mand med en fortid i Revolutionsgarden, to dage efter valget: "Vi revolutionsgardister plejer at være Khameneis fodfolk. Vi havde ingen politisk rolle".

Præsidentkandidat Medhi Karroubi sagde i et tv-interview: "De er ved at tage revolutionen fra os". Med 'os' mente Karroubi præsteskabet, som han selv er veteran i. Ifølge Karroubi støtter 'de lavtuddannede elementer i præsteskabet' Revolutionsgarden.

"Reelt har de udløst undtagelsestilstand", mente Ali Alfoneh. Det blev en uerklæret undtagelsestilstand, som blev total i bl.a. byen Kermanshah, tæt på grænsen til Irak. I Kermanshah strammede regimet grebet med indsættelse af ekstra revolutionsgardister og totalt udgangsforbud, fordi butiksindehavere $\mathrm{i}$ byen gennemførte en næsten altomfattende strejke. Desuden tilbød to klaner i byens store kurdiske mindretal at sende væbnede mænd til Teheran for at beskytte demonstranterne.

Håbet om en ny iransk revolution var fra starten illusorisk, og der var meget lidt, omverdenen kunne gøre for at bremse Irans elitestyrke Revolutionsgarden og dens civile tæskehold, Basij-militsen. Selv om det næppe kan kaldes en revolution, har især de unges fremmarch og det åbne slagsmål i præstestyret betydet begyndelsen til enden for den islamiske stat.

Den søger at forsvare sin legitimitet, men hvert knippelslag rammer dens egen legitimitet. Udviklingen 
viser, at den 30-årige revolution er blevet for gammel og for repressiv for revolutionens børn og dem, som er født i årene efter. Det handler nu om meget mere end valgsvindel for Mahmoud Ahmadinejad.

Råbene om ændring er bragt til tavshed af våben før, men nu pibler de frem i alle Irans kroge. Der er simpelthen for mange utilfredse til at undertrykke permanent, og derfor er situationen radikalt anderledes end fx under studenteroprøret $\mathrm{i}$ 1999.

Dengang var reformatoren Mohammad Khatami blevet præsident to år tidligere, men en konservativ modoffensiv gjorde ham næsten magtesløs. Khatami blev genvalgt i skæbneåret 2001, men blev nu også undergravet af sin kollega i USA, George W. Bush. Bush-doktrinens 'ondskabens akse' gav Irans onde præster den ydre legitimering til at svinebinde oppositionen. Resultatet blev Mahmoud Ahmadinejad i 2005.

Des længere tid demonstranterne holder stand, des mere svækkes regimet i opgør imellem på den ene side globaliseringens instrumenter som mobiltelefonen, internet, råb og enkelte brosten og en formidabel militærmagt på den anden.

\section{Som Østeuropa anno 1989}

Stemningen op til valget mindede mig om første fase af alle de revolutioner, som jeg med stor fryd rejste rundt til i Østeuropa i 1989. Efter at have oplevet kommunistiske diktatorer falde, ville jeg være verdens lykkeligste journalist, hvis jeg også på nært hold skulle opleve den iranske diktator falde.

Det var de samme barrierer af angst, som bragede sammen med uventet styrke for både demonstranter og magten i Teheran og mange andre iranske byer som dengang $\mathrm{i}$ østeuropæiske byer. Først kom de unge, så deres forældre og bedsteforældre. Stadig flere børn kom med. Også det var nyt, for iranerne har under tidligere demonstrationer ladet børnene blive hjemme hos bedsteforældrene. Men nu var bedsteforældrene også med i forvandlingen til en folkelig frihedsbevægelse.

Det mindede dog alligevel mest om Iran selv og om den islamiske revolution i 1979. Hvis sammenligningen skulle holde, skulle østeuropæerne dengang have været på gaderne imod Stalin og for en genoptagelse af idealerne fra bolsjevikkernes revolution i 1917. Det var som bekendt ikke østeuropæernes ærinde i 1989. De var i gaderne imod kommunismen og alt dens væsen og for demokrati.

For iranerne var det før valget en kamp imod deres Stalin, Ahmadinejad, og for reformkandidaten Mousavi, der ville genoplive idealerne, som den islamiske revolutions fader ayatollah Khomeini var bærer af deres Lenin. Sådan var det i hvert fald på overfladen, da masserne 
fulgte Mousavis formulering af målet, som ikke på nogen måde antastede den islamiske stat.

Men i menneskehavet under overfladen af det løsslupne politiske karneval talte især de unge meget om deres ønske om sekularisering, adskillelse af moske og stat.

Det var tidligere dødsensfarligt at tale om, men under dette mellemspil af større frihed, som præsteskabet tillod under valgkampen, blev der talt meget om drømmene om reel demokratisering.

Det såkaldt islamiske demokrati havde mange unge og højtuddannede vendt ryggen, men de gav udtryk for, at opgøret med præstestyret "ligger langt ude i fremtiden", som mange sagde.

I gadens debatter blev ivrigt gisnet, om tidsperspektivet var fem, ti eller tyve år. Blandt de, som sammenlignede Østeuropa anno 1989 og Iran anno 2009, var Zbigniew Brzezinski, amerikansk sikkerhedsrådgiver under Irans revolution $\mathrm{i}$ 1979 og central meningsdanner om Solidaritetsbevægelsens fremmarch kort efter i Polen.

\section{Nationalismen til forskel}

Brzezinski understregede i et tv-interview, at det kan blive en meget lang begyndelse til enden for præsteskabet. Den store forskel til Østeuropa ser han i den 'intense nationalisme' i 1989. Det var en folkeopstand imod Moskvas overmagt.
"Iranerne kæmper ikke samlet imod en fremmed overmagt. Det gør dem mere splittede”, sagde Brzezinski.

Dertil kan siges, at nationalismen også er stærk i Iran, men mest på Ahmadinejads fløj, der bruger det også under kommunismen kendte trick at mobilisere til samling imod ydre fjender.

Men Irans frihedsbevægelse $ø n-$ sker i stedet deres land forsonet med Vesten og tæt samarbejde vestover.

Og så kom protestens metamorfose. Råbet 'Død over diktatoren', Ahmadinejad, blev til 'Død over Khamenei’, Den Øverste Leder. Khamenei er ikke nogen populær mand i den brede befolkning, endsige særlig agtet blandt de religiøse lærde, da han end ikke var ayatollah, da han blev udset til posten som landets øverste.

Med dødsråb imod Khamenei overskred mange demonstranter en grænse, det største tabu. De vendte sig nu imod det præsteskab, som Mousavi er en integreret del af. Han var nær ven af Khomeini under revolutionen. Og det var Khomeini, der gjorde Mousavi til regeringsleder i 1981. Khamenei havde en anden kandidat til posten, men blev tilsidesat af Khomeini, der ville have sin nære allierede Mousavi i spidsen for regeringen. Khameneis had til Mousavi har som så meget andet $\mathrm{i}$ Iran revolutionen som datomærke.

Mange elskede revolutionssymbo- 
ler faldt i de dage. Selv om oppositionen altid har frygtet Basij-militsen, har det frivillige korps været elsket af mange almindelige iranere. Basij betyder massemobilisering og har indtil nu været den eneste tilladte massemobilisering, der ud over en fast stab har tiltrukket mange mænd som kvinder til korpsets mobiliseringsstyrker. En beskeden aflønning for at stå parat har tiltrukket mange fattige og arbejdsløse.

Basij-militsernes hidtidige heltestatus blandt mange iranere går tilbage til krigen mod Irak. Basij-militsen blev skabt, da Irak invaderede Iran i 1980 som et korps af frivillige, der var parate til martyrdøden for Khomeinis stat. Basij-militsen blev brugt i fortroppen imod irakerne og som levende mineryddere for de regulære iranske styrker. Titusinder af basiji'er blev sendt i døden.

Basij-militsen fik ny eksistensberettigelse i den konservative offensiv imod reformpræsidenten, Mohammad Khatami. Her lærte Khatami-tilhængere deres knipler at kende.

Basij-militsen har nye kronede dage som religiøst tæskehold, der blev sendt ud for at se, om de kunne banke demonstranterne fra gaden, så Revolutionsgarden kunne undgå at rykke ud.

Khamenei truede i sin fredagsbøn ugen efter valget med at sætte Revolutionsgarden ind, men ville uden tvivl helst undgå det. Næppe af hensyn til demonstranters liv, men for at redde sit eget politiske liv. Præste- skabet husker utvivlsomt, at da shahen sendte sine elitestyrker på mordtogter, var det med til at berede hans fald. Nu har den iranske frihedsbevægelse fået sin helt egen dynamik, der går langt ud over striden om valgsvindel.

Når Khamenei sætter Revolutionsgarden ind, kan det dårligt betyde andet end et blodbad, som vil betyde mobilisering imod Khamenei, selv om han har militære midler til at rydde gaderne.

Fredagen efter blev truslen skærpet i den vigtigste fredagsbøn på Teherans Universitet. Nu fik demonstrationsledere stillet henrettelse i udsigt for at 'gå i krig imod Allah'.

\section{Moralsk støtte}

USA's Barack Obama har gjort det rigtige: at give protesten al mulig moralsk støtte, men afholde sig fra direkte politisk indblanding. Obama har svækket præsternes tidligere stærke kort: USA som 'den store satan'. Nu virker det kun på fanatikerne, som der er få af blandt almindelige iranere.

Obama har været udsat for megen kritik fra fløje, som kræver åben konfrontation med Iran. Er det en katastrofe som på Tiananmen Pladsen i Beijing 1989, som kritikerne ønsker i Teheran? Enhver direkte politisk indblanding kan kun øge faren for at langt større blodbad i Iran, end vi hidtil har set. Vesten forhandlede med Mao Tse-Tung og 
med Stalin og må også forhandle med Ahmadinejad. Iran - ikke Ahmadinejad - må gives indrømmelser som ret til begrænset og skarpt overvåget berigelse af uran.

Konflikten om Irans atomprogram må ikke behandles af Vesten på en måde, som fører til yderligere undertrykkelse i Iran.

Obama forstår historiens lange sømme og betydningen af USA's tidligere indblanding til skade for Irans demokrater. Og hvilke venner har præstestyret overhovedet tilbage? Vigtigst for Teheran er nok Rusland, hvor præsident Dmitrij Medvedev udtrykte 'fuld tillid til valgresultatet'. Og Medvedev ved, hvad han taler om med Kremls evner for valgfusk.

Venezuelas præsident Hugo Chavez kaldte sig Ahmadinejads 'allerbedste ven'. Chavez menes at have svindlet ved alle valg i landet siden 2003 og har leveret provokationer nok til USA til et langt liv. Men takket være Venezuelas olie har han altid formået et vist comeback.

Der er ingen 'happy ending' for Iran ifølge Caracas Chronicles: "Trist nok levner Venezuelas erfaringer ikke meget håb for tilhængerne af Irans Mousavi. Vi har for længe siden lært ikke at undervurdere petro-diktaturets evne til at ignorere det, som sker i gaderne". I Mellemøsten står Syrien nu som Ahmadinejads bedste ven ved siden af Hizbollah og Hamas.

Demonstrationer udsletter ikke mullaher, og twitter dræber ikke dik- taturer. Det kan Burmas munke også tale med om. Dette har intet at gøre med den dominerende shiaislam i Iran. Det er et præsteskabs kamp for politisk overlevelse, og dets død kan blive en meget pinefuld og langvarig affære.

Når revolutionen tæver og myrder sine egne børn, er det begyndelsen til enden for den.

\section{Kvindernes korte pusterum}

Valgkampens korte politiske forår kom ikke mindst kvindebevægelsen til gode. Mens aktivister, der samler underskrifter ind for kravet om kvinders ligestilling for loven, normalt ryger ind og ud af fængsler, lod myndighederne dem være i fred. De frygtede dog igen at blive jaget vildt, hvis Ahmadinejad blev genvalgt. Ahmadinejads 'kvindekommissær', Zahre Tabibzadeh Nouri, lovede imidlertid varig forbedring af ytringsfriheden på en pressekonference tre dage før valget: "Vi har åbnet for en helt fri debat om alt vedrørende kvinder".

Da jeg som spurgte hende, om det også ville gælde de kvinder, der samler underskrifter ind for ligestilling af kønnene i lovgivningen, fik tonen en noget anden lyd: "Selvfølgelig må det foregå inden for det islamiske demokratis rammer".

I en park i Teherans centrum er seks unge kvindesagsaktivister i gang med at overbevise kvinder om, at de skal skrive under på krav om lige- 
stilling. 'Du skal kende dine rettigheder', hedder det på plakater for målet at få underskrifter fra en million kvinder. Men det går trægt. "Jeg må først spørge min mand, og han siger nok nej", siger en kvinde med en barnevogn.

Aktivisterne ser valgkampen som et åndehul til at styrke deres kampagne. "Mange kvinder er dog også i denne tid bange for at stikke hovedet frem, men de er ivrige efter at høre om deres rettigheder", siger Homa, der ikke fik en eneste underskrift den dag.

Kampagneleder og sociolog Nafiseh siger: "Vi vidste, at det ville blive sejt, da vi startede kampagnen i 2006, men vi undervurderede alligevel, hvor svært det ville blive at nå en million underskrifter".

For hende er kampagnen alligevel en stor succes: "Vi har brudt tavsheden om diskriminering af kvinder. Alle præsidentkandidater må nu forholde sig til sagen".

Bevægelsen kaldte sig fra starten en 'ikke-ideologisk' bevægelse, så både verdslige og religiøse kvinder kunne deltage. Gennem gadeteater, bøger og pjecer fortælles pædagogisk om diskrimineringen i ægteskabs-, familie- og arveret og det forhold, at et kvindeligt vidne kun tæller for det halve i straffesager. I Teheran har bevægelsen nu over 600 kvinder og mænd på 'skolebænken' om lovgivningen med advokater, psykologer og sociologer som lærere.
Nafiseh kalder sit seks dages fængselsophold for nylig for 'en meget positiv oplevelse'.

Hun og fem andre aktivister blev arresteret 1 . maj under en demonstration. De blev modtaget med smil af flere kvindelige fængselsbetjente. "Et par stykker af dem takkede os for at turde kæmpe for iranske kvinders sag", fortæller hun. Alle nytilkomne til kvindefængslet blev henvist til Nafiseh, som i timevis underviste dem i deres rettigheder.

Parvin, der har en betinget dom på et halvt år som en af de superaktive kvinder, siger, at hun også har oplevet ivrige studiekredse om kvinders rettigheder under sine ophold bag tremmer.

"Kvindebevægelsen blev stærk cirka samtidig med, at Ahmadinejad kom til magten i 2005. Vi og Ahmadinejad startede arbejdet samtidig", siger hun leende.

\section{Ahmadinejads land}

Aktivisterne var uenige, om de skal stemme ved præsidentvalget. På en friluftsrestaurant, hvor vandpiber går rundt, råber omkring 20 kvinder og enkelte mandlige aktivister $\mathrm{i}$ munden på hinanden.

"Hvis vi vil af med Ahmadinejad, må vi stemme på det mindst onde, (Mousavi)", siger en biologistuderende. "Det ændrer intet, for han hænger godt fast i præsternes kjoler", siger hendes sidekvinde. Da vi forlader stedet, ser forsamlingen til 
sin rædsel en gigantisk plakatsøjle for Ahmadinejad med påskriften, at han støttes af restaurantkæden.

Der blev diskuteret meget den aften om kvindebevægelsens krav om adskillelse af stat og moske, en sekulær stat.

"Det er stadig farligt åbent at støtte sekularisme", siger Parvin, der fortæller, at betjente og forhørsledere altid anklager dem for at modtage penge fra Vesten: "De nægter at tro, at nogen vil arbejde gratis for noget som helst".

Debatten om der skulle stemmes eller ej, hænger sammen med, at især unge kvinder ser det som totalt umuligt at opnå ligestilling under et religiøst styre.

Fordømmelsen af kvindebevægelsen hænger over pressekonferencen i Propagandaministeriet. Totalt tildækket i sorte gevandter fortæller Zahre Tabibzadeh Nouri, Ahmadinejads rådgiver, at hun om nogen varetager kvindernes sag. "Og jeg har 98 procent af kvinder, ja af alle iranere bag mig i støtten til islamisk lovgivning", siger hun.

Om kvindebevægelsens ligestillingskrav siger hun: "En million underskrifter er latterligt lidt. Jeg kan hurtigt få fem millioner Basij-kvinders underskrift på vore loves fulde retfærdighed".

Nouri ønsker mig varmt velkommen til Iran, men mener, at jeg helt misforstår situationen. "Vi taler ikke om diskriminering, men om retfærdighed. Ulighederne mellem mænd og kvinder betyder selvfølgelig, at de må have forskellige rettigheder. Kvinderne har vores højeste prioritet, for vi tillader for eksempel ikke, at de arbejder i en mine i graviditetens sidste måned".

En mandlig iransk journalist siger, at hun ikke svarer på spørgsmålet og peger på diskrimination, når det gælder, at manden som regel får børnene efter skilsmisse, og at kvinders arveandel er mindre end mænds.

"Man kan forstå, at en dansker ikke har begreb om vores muslimske retsorden, men jeg er træt af iranere, som intet ved, og vil ikke forklare en iraner om detaljer i hans egen lov. Når det gælder det utænkelige, at vort folk vælger Mousavi som præsident, tager jeg det helt roligt. For vi har islamisk demokrati, så det er naturligt, og mit arbejde for kvinder går videre efter valget", siger Nouri.

"Det er en flok basij-kællinger", hvisker en iransk journalist, da hun forlader salen med stort følge af bølgende sorte gevandter.

\section{En stærk kvinde}

Senere samme dag siger kvinden, som mange spåede ville blive Irans førstedame, Mousavis kone Zahra Rahnavard, til selvfølgelig en amerikansk journalists spørgsmål om hendes lighed med USA's førstedame: "Jeg er ikke Michelle Obama". Iranske kvinders rettigheder slog 
overraskende stærkt igennem i valgkampen. Det skyldes ikke mindst den 62-årige Zahra Rahnavard, professor i kunsthistorie ved Teherans Universitet. En stærk kvinde, 'skrap moster', som flere aviser kaldte hende, før hun blev lagt på is af de statskontrollerede medier efter valget. Rahnavard har været kvindesagsforkæmper fra sin grønne ungdom. Når hun blev en af valgkampens mest profilerede, skyldes det, at hun var næsten mere aktiv i valgkampen end præsidentkandidaten selv. Og hun lover at være "overordentlig synlig for alle iranske kvinders sag". Sammen med ægtemanden vil hun "ændre Iran og bekæmpe fundamentalismen".

Den lille kvinde med sort chador over en lyseblå cowboyjakke og med en hippieagtig spraglet taske foran sig gestikulerer vildt, da hun går til angreb på Ahmadinejad. "Han lyver om alt", råber hun om præsidentens påstand, at hun har svindlet sig til sin professortitel.

Under Ahmadinejads udrensning af liberale intellektuelle kort efter sin tiltrædelse blev Rahnavard, Irans første kvindelige rektor efter den islamiske revolution i 1979, fyret fra den post ved Alzahra Universitetet i Teheran. "Ahmadinejad må undskylde over for ikke bare mig, men alle iranske kvinder for løgnene om mig. Ellers rejser jeg sag imod ham". Hun lover, at hvis hendes mand vinder valget, vil de sammen "udrydde al grund til frygt blandt kvinder, især de fattigste, og tage os af alle kvindernes problemer".

Til spørgsmålet om Mousavi vil opløse moralpolitiet, der chikanerer og arresterer kvinder, der ikke respekterer præstestyrets krav til kvinders påklædning: "Vi vil gøre alt for, at Iran slipper af med moralpolitiet".

Og hvad med andre former for myndigheders snagen i privatlivet? "Det vil vi også gøre alt for at få bremset", siger hun, men kan af gode grunde ikke love noget. De gode grunde hedder præsteskabet og alt dets uvæsen.

Hun fortæller, at ægtemanden deler hendes synspunkter om kvinders ligestilling: "Ja, fuldt ud, ellers kunne vi ikke have været gift i over 40 år”.

Om det påbudte tørklæde, siger Rahnavard: "Også kvinderne skal følge Koranens bud, men det udelukker ikke, at kvinder selv kan vælge. Om hun bærer den ene eller den anden form for hovedbeklædning er hendes egen sag, bare hjertet banker for Iran".

Det lykkedes ikke at få et klart svar på, om kvinder skal kunne fravælge tørklædet.

Selv valgte hun det fulde udstyr, "efter at jeg blev meget religiøs".

At hun og ægtemanden vil følge Khomeini og revolutionens bud i et og alt, efterlader hun ingen tvivl om. "Imam Khomeini sagde, at alt skal gøres for kvinders ligeret. Den sociale revolution skal nu reddes fra Ahmadinejads forræderi imod Kho- 
meini og revolutionen”. Ifølge Rahnavard har Ahmadinejad forsøgt at forhindre kvinders adgang til universiteter.

Hvordan hænger det sammen med, at mindst 63 procent af Irans studerende er kvinder?

"Jeg er næsten sikker på, at han har en hemmelig plan om at forhindre kvinder i at få høje uddannelser. Når han hævder, at mine mange grader er illegitime, er det jo for at signalere, at sådan noget kan kvinder ikke opnå legalt".

Dagen forinden var ægtemanden blevet forhindret $i$ at tale til op mod 100.000 deltagere på et stort stadium, $30 \mathrm{~km}$ fra Teheran. Strømmen til mikrofonen forsvandt, da Mousavi gik på talerstolen. "Det var ren sabotage for at gøre ham tavs, men det skal ikke lykkes", siger Zahra Rahnavard.

\section{Bag chadoren}

Anonymt vil en kvindelig betjent med sort chador over uniformen godt fortælle, hvad der bekymrer hende mest: "Jeg er for Ahmadinejad og frygter, at friheden misbruges af Mousavis vilde unge".

Men mange af de 'sorte fugle', dækket af chador fra top til tå, støtter imidlertid Mousavi. Det kan ses af de grønne bånd over det sorte, Mousavi-bevægelsens farve. At oprøret også bobler under chadorer, viser den 60-årige Mehrangiz, som siger: "Min mand kræver, at jeg stemmer på Ahmadinejad, men det bliver over mit lig. Han kan lade sig skille. Det kan han".

Også hun henviser til tv-debatterne, som skruede valgtemperaturen markant op. Blandt de mange positive tegn var, at mange lagde sig imellem, når Ahmadinejad-modstandere og tilhængere kom $\mathrm{i}$ håndgemæng. Og da volden brød løs, kom mange Mousavi-tilhængere betjente til undsætning, når demonstranter gik til modangreb.

Læreren Shirin henviser til, at over 60 procent af Irans befolkning er under 30 år og siger: "Der er håb om, at Mousavi vinder, men det er kun befolkningen og især de unge, som for alvor kan ændre Iran. De er desværre mest optaget af at få større sociale frihedsrettigheder og ikke så meget af politik. Hvis ikke iranerne lærer deres rettigheder at kende og kæmper for dem, så vil præsteskabets dominans bare fortsætte".

Men iranerne har vist med hidtil uset styrke, at de er det mest forandringsparate folk i

Mellemøsten. Og en mangfoldighed af kvindebevægelser er i front. Som en demonstrant udtrykker det: "Kvinderne er de eneste sande mandfolk i Iran".

Journalist Vibeke Sperling var udsendt 